\title{
Influence of corn processing provided in the diet on the ruminal dynamics of dairy steer
}

\author{
Fernando Miranda de Vargas Junior ${ }^{1}$, Luis Maria Bonnecarrère Sanchez ${ }^{2}$, Francisco Stefano \\ Wechsler ${ }^{3}$, Waldmaryan Bianchini ${ }^{3}$, Marcus Vinicius Morais de Oliveira ${ }^{4}$, Patrick Schmidt ${ }^{5}$ \\ 1 Universidade Federal da Grande Dourados - UFGD \\ 2 Universidade Federal de Santa Maria - UFSM. \\ 3 Universidade Estadual Paulista -UNESP - FMVZ \\ ${ }^{4}$ Universidade Estadual de Mato Grosso do Sul/Unidade Universitária de Aquidauana - UEMS/UUA. \\ 5 Universidade Federal do Paraná - UFPR.
}

\begin{abstract}
The objective of the present study was to evaluate the ruminal dynamics of dairy steer fed diets containing whole corn grains, grains ground into grits or whole grain treated with urea. Thus, six rumen-fistulated animals were kept in confinement and fed diets with similar contents of energy and protein. The diet was formulated with 40:60 roughage:concentrate ratio in the dry matter using sorghum silage as roughage. The experiments followed a $3 \times 3$ latin square design, with three animals and three periods and they were repeated eith-er two or four times depending on the studied parameter, totaling six or 12 replicates per diet. Corn grain treatment did not affect the $\mathrm{pH}$ of the ruminal fluid neither the ruminal degradability of dry matter, acid detergent fiber and cellulose. All diets provided a concentration of amoniacal nitrogen suitable for ruminal microbial growth; however, for animals fed whole corn grain treated with urea, this concentration was significantly lower. Bacterial activity was lower in animals fed diets containing ground corn and they do not differ among animals fed whole corn grain or corn grains treated with urea.
\end{abstract}

Key Words: bacterial activity, bovine, in situ degradability

\section{Influência do processamento do milho fornecido na dieta na dinâmica ruminal de novilhos leiteiros}

RESUMO - Objetivou-se com este trabalho avaliar a dinâmica ruminal de novilhos leiteiros recebendo dietas contendo grão de milho inteiro, milho moído na forma de quirera ou milho inteiro tratado com ureia. Para isso, foram mantidos em regime de confinamento seis animais fistulados no rúmen alimentados com dietas com teores semelhantes de energia e proteína. A dieta foi formulada com relação volumoso:concentrado de 40:60 na matéria seca e continha silagem de sorgo como volumoso. O delineamento utilizado foi na forma de um quadrado latino $3 \times 3$, com três animais e três períodos, e foi repetido duas ou quatro vezes conforme o parâmetro estudado, totalizando seis ou 12 repetições por dieta. O tratamento do grão de milho não influenciou o pH do líquido ruminal nem a degradabilidade ruminal da matéria seca, fibra em detergente ácido e celulose. Todas as dietas propiciaram concentração de $\mathrm{N}$-amoniacal adequada para o crescimento microbiano ruminal; todavia, nos animais alimentados com grão de milho inteiro tratado com ureia, essa concentração foi significativamente menor. A atividade bacteriana é menor em animais alimentados com dietas contendo milho moído e não difere entre os animais alimentados com grão de milho inteiro ou grão de milho inteiro tratado com ureia.

Palavras-chave: atividade bacteriana, bovinos, degradabilidade in situ

\section{Introduction}

The oldest and most commonly used methods for grain processing are those that cause physical destruction of cells by mechanical means. As a consequence, corn grain, because of its lining layer, is usually ground to improve starch digestibility, by making the starch more exposed to the action of ruminal microorganisms and to the impact of enzymes from the digestive tract.
According to Vargas Junior et al. (2008), the treatment of corn grains with urea is of interest because, in addition to allowing the storage of the cereal on the farm under high humidity conditions and free from pests, it also acts in the pre-processing of the cereal, inasmuch as urea, because of being diluted in water and mixed with corn in a sealed environment, causes microfissures in the grain lining layers, thus facilitating the access to bacteria and the degradation of starch granules. However, Alcade \& Andrade (1997) 
underlined that, despite being a common practice, the processing of corn grains often does not have the expected efficacy.

The rate of ruminal microbial activity depends directly on the amount and availability of carbohydrates and nitrogen in the rumen (Theurer, 1986) therefore on the type of food and the treatment to which this food is subjected to (Potter, 1971). According to Huntington (1989), diets with high grain content, consequentely with a higher proportion of readily fermentable carbohydrates, tend to reduce ruminal $\mathrm{pH}$, favoring bacteria that are less sensitive to low $\mathrm{pH}$, such as amylolytic and saccharolytic bacteria, increasing the use of ammonia and decreasing its concentration in the rumen. In addition, the number and the activity of ureolytic bacteria attached to the wall of the rumen are increased. Thus, ruminal $\mathrm{pH}$ reflects the balance between the production rates of volatile fatty acids, the input of buffers through the saliva, and the release of gases from ruminal fermentation, via eructation (Hobson \& Steward, 1997). According to Silva \& Leão (1979), the highest absorption of volatile fatty acids occurs under low pH, i.e. from 5.6 to 5.8. In addition, according to Allen (1997), an exceedingly low $\mathrm{pH}$ reduces appetite, ruminal motility, microbial growth, and fiber digestion, possibly leading to laminitis, ruminal ulcerations, hepatic abscesses or even to the death of the animal. According to Owens \& Goetsch (1993), diets with a high proportion of grains tend to reduce the $\mathrm{pH}$ of the ruminal fluid and to decrease the ruminal degradability of fiber due to the lower survivorship of cellulolytic and hemi-cellulolytic bacteria.

According to Rooney \& Pflugfelder (1986), depending on the degree of grinding of the corn grain, the velocity of ruminal degradation will vary and, as a consequence, the amplitude in the concentrations of volatile fatty acids and of the ammoniacal nitrogen will be higher in the ruminal environment. Therefore, the goal of this experiment was to test the effect of the method of provisioning of corn in the diet (whole grain, grains ground into grits, or whole grains treated with urea) in the ruminal dynamics of dairy steer.

\section{Material and Methods}

This study was carried out in the Setor de Nutrição Animal, Departamento de Zootecnia, Universidade Federal de Santa Maria (UFSM), in Santa Maria, state of Rio Grande do Sul, southern Brazil. Six castrated dairy steer, with an average initial live weight of $219 \mathrm{~kg}$ and fitted with ruminal canula, were used in the experiments. The animals were kept in confinement, fed sorghum silage based diet with forage:concentrate ratio of 40:60.

All diets had similar levels of energy and protein and differed only with respect to the type of corn grain (ground or whole), or whether it was treated or not with urea. Three types of corn provisioning were assessed: whole grain, grain ground into grits, and whole grains treated with urea (Table 1).

Corn grains were ground into grits by using a hammer mill without a sieve. For whole grains treated with urea, corn grains were treated with a $40 \%$ aqueous solution, so urea accounted for $2 \%$ of the total corn dry weight to be treated. To facilitate the application and to ensure complete homogenization, grains were mixed to the urea solution in a horizontal mixer and then covered with a plastic tarp to prevent volatilization of ammonia and finally, the solution was stored for four weeks in a brick shed.

The method used for investigating ruminal disappearance of dry matter (DM), acid detergent fiber (ADF) and sorghum silage cellulose was based on in situ degradability according to the procedure adopted in Hernandez et al. (1998). The experimental period consisted of three 21-day periods: on the $15^{\text {th }}$ day of each period, two $5 \times 10$-cm polyester bags with 48-mm mesh size were introduced into the rumen of each animal for every incubation interval. Each bag was

Table 1 - Composition of the experimental diets, in dry wheight, and respective levels of crude protein (CP) and digestible energy

\begin{tabular}{lccc}
\hline Ingredient & \multicolumn{3}{c}{ Corn grain } \\
\cline { 2 - 4 } & Whole grain & Ground grain & Whole grain treated with urea \\
\hline Sorghum silage, kg & 40.0 & 40.0 & 40.0 \\
Whole corn grain, kg & 40.6 & - & - \\
Ground corn grain, kg & - & 40.6 & - \\
Whole corn grain treated with urea, kg & - & - & 41.2 \\
Soybean meal, kg & 17.6 & 0.6 & - \\
Urea, kg & 0.6 & 0.6 & 0.6 \\
Salt (NaCl), kg & 0.6 & 0.6 & 0.6 \\
Calcitic limestone, kg & 0.6 & 14.60 & 14.89 \\
Crude protein (CP), \% & 14.60 & 65.37 & 61.98 \\
Digestible energy, \% & 63.14 & \\
\hline
\end{tabular}

\footnotetext{
${ }^{1}$ Vargas Junior et al. (2008)
} 
identified with insoluble ink and received $15 \mathrm{mg} / \mathrm{cm}^{2}$ of silage sorghum dry matter previously ground in a 4-mm mesh size willey mill. Each bag was sealed with an automatic heat sealer.

Incubation procedures followed the guidelines of AFRC (1992), following the method of sequential incubation, i.e. the bags first inserted into the rumen were the first to be removed. The bags were placed in a polyamide bag $(12.5 \times 21 \mathrm{~cm}, 1-\mathrm{mm}$ mesh size $)$ that was attached to an anchor with lead weights and an average total weight of $250 \mathrm{~g}$. The anchor was tied to a 50-cm nylon thread to ensure the immediate immersion and movement of the bag in the ruminal contents and to facilitate its removal, inasmuch as the end of the thread was fixed near the lid of the canule. Incubation times, following the order of the placement of the bags in the rumen, were $96,72,48,24,12,8$, and $0 \mathrm{~h}$, respectively. At the end of the assay, all bags were removed from the rumen and, together with the zero-time bags, were washed by vortexing until the water was completely clear. After washing, the bags were placed on a $65^{\circ} \mathrm{C}$ incubator for $72 \mathrm{~h}$. Analyses were later conducted to determine the contents of dry matter, acid detergent fiber, and cellulose in silage samples that were incubated in the rumen and of the respective residues that remained in the bag after ruminal incubation, following the guidelines described in the AOAC (1984) and by Goering \& Van Soest (1970).

The determination of the percentage of DM, ADF, and cellulose that disappeared in the rumen at each interval was obtained as follows: ruminal disappearance of dry matter $(\mathrm{DM})$, acid detergent fiber $(\mathrm{ADF})$ or cellulose $=[(\mathrm{DM}, \mathrm{ADF}$ or incubated cellulose (g) -residual DM, ADF or cellulose after ruminal incubation (g)) / g of incubated DM, ADF or cellulose $] \times 100$. Following the estimates of parameters for ruminal degradation of DM, ADF and cellulose, data on disappearance at different intervals were analyzed. Partial degradation data were adjusted according to the model of Orskov \& McDonald (1979) Dg = a + b (1- exp $\left.{ }^{-c t}\right)$, in which $\mathrm{a}=$ soluble fraction degraded at time zero; $\mathrm{b}=$ insoluble, potentially degradable fraction; $\mathrm{c}=$ fractional rate of degradation of $b$ fraction per unit of time; and $t=$ incubation time. The effective degradability (Ede) for each food type was calculated using the formula Ede $=a+[(b * c) /(c+k)]$, in which $\mathrm{k}=$ the passage rate, as described by McDonald (1981).

The experimental design used to assess the effect of the diets on the ruminal degradability of DM, ADF and sorghum silage cellulose and their respective effective degradabilities were conducted in a $3 \times 3$ latin square with two replicates, such that columns represented the animals (six animals) and lines represented the intervals (three intervals), for a total of six replicates per mode of corn processing. The data were subjected to analysis of variance and to LSMEANS mean comparison test using the statistical package SAS (2003).

On the 21st day of each experimental interval during the degradability assay, samples were also obtained from the ruminal liquid to determine its $\mathrm{pH}$, the level of amoniacal nitrogen, and bacterial activity. A vacuum pump were used to remove an aliquot of $50 \mathrm{~mL}$ of ruminal liquid, which was filtered with a cotton fabric and kept heated at approximately $39^{\circ} \mathrm{C}$, as well as the material that came into contact with the liquid.

Six samples of ruminal liquid were obtained at 1.5-h intervals to determine its $\mathrm{pH}$ by using a digital potentiometer: the first sample was removed before the morning feeding (zero time) and the remaining samples at 1.5, 2.5, 3.5, 5.5, and $8.5 \mathrm{~h}$ after feeding. Food and water were provided in abundance, although the time for solid diet feeding was restricted to $1.5 \mathrm{~h}$ to decrease the effects of a constant input of food into the rumen.

The concentration of amoniacal nitrogen was determined immediately after filtration by removing a $10-\mathrm{mL}$ aliquot of ruminal liquid and centrifugation at $5000 \mathrm{rpm}$ for $15 \mathrm{~min}$. After that, the concentration of amoniacal nitrogen was measured (mg N/100 mL), using the technique described by Fenner (1965).

Bacterial activity was measured by reduction of methylene blue immediately after the filtration of the ruminal liquid, following the procedures described by Dirksen (1981). A 19-mL volume of ruminal liquid was pipetted at a constant temperature $\left(38\right.$ to $40^{\circ} \mathrm{C}$ ) in a test tube and added to $1 \mathrm{~mL}$ of a $0.03 \%$ solution of methylene blue. The sample was then homogenized and the reduction time was measured using as a control another test tube with $20 \mathrm{~mL}$ of ruminal fluid. Time was measured between the moment of homogenization of ruminal liquid with methylene blue and the time for it to become similar to the standard as an indication of the number of seconds necessary for reduction. Reduction times were classified into three classes: up to $180 \mathrm{~s}$, from 180 to $360 \mathrm{~s}$, and above $360 \mathrm{~s}$, representing a highly active, moderate or poorly active flora, respectively.

The experimental design used to assess the influence of the diet on the $\mathrm{pH}$, amoniacal nitrogen and bacterial activity in the ruminal liquid was a $3 \times 3$ latin square, repeated four times (12 replicates) for $\mathrm{pH}$ and amoniacal nitrogen, and twice for bacterial activity (3 replicates). The obtained data were submitted to analysis of variance as a function of time and to the LSMEANS test for comparison of means using statistical package SAS (2003). 


\section{Results and Discussion}

Corn grain treatment did not influence $(\mathrm{P}>0.05)$ the disappearance of dry matter, acid detergent fiber or cellulose from sorghum silage in any of the ruminal incubation periods (Table 2). Therefore, the hypothesis of a possible reduction in ruminal $\mathrm{pH}$, associated with a higher rate of degradation of processed corn grains,, would influence fiber degradation by ruminal microorganisms was not corroborated. Vargas Junior et al. (2008) also did not find evidence that the processing of corn grains influenced the total digestibility of these diet components.

However, in this experiment, the ruminal degradability of sorghum silage increased with incubation time, stabilizing after 72 hours (Table 2). Disappearance values of DM and ADF, when compared to the ways of corn processing in each time interval, were similar to each other and did not differ in any of the intervals. But, for cellulose disappearance, these values were not as homogeneous, but still did not differ among experimental diets. Hernandez et al. (1998), studing Pennisetum purpureum and Pennisetum glaucum, found values similar to those in the present study for DM disappearance, particularly for longer incubation periods.
In the present experiment, fractions "a” and " $b$ ", the degradation rate " $c$ ", the degradation potential $(a+b)$, the lag time and the different effective degradations of sorghum silage were not significantly influenced by corn grain treatment, regardless of whether they were assessed in terms of DM, ADF, or cellulose (Tables 3, 4 and 5). These results indirectly show that the ruminal environment was not affected by the processing of corn to the point of influencing ruminal degradation. Beauchemin et al. (1994), using the same level of concentrate, but with ground barley as the forage, and Oliveira et al. (2003), in a study on sorghum silage with the same forage:concentrate ratio and an equal proportion of ground corn in the diet, observed values of "a", "b”, and effective degradabilities similar to dry matter. Bürger et al. (2000), working with the same level of concentrate and ground corn in the diet, but using coastcross hay, found lower values of dry matter, and the influence of the forage properties on the degradability of dry matter was highlighted.

The "a" fraction estimated for the degradability of ADF and cellulose, which was expected to be null inasmuch as none of these fractions is theoretically soluble in water, showed relatively high values, with an average of $7.74 \%$

Table 2 - Disappearance of dry matter, acid detergent fiber, and cellulose of sorghum silage in six intervals of ruminal incubation

\begin{tabular}{|c|c|c|c|c|c|c|c|}
\hline & \multicolumn{7}{|c|}{ Time of ruminal incubation (h) } \\
\hline & 0 & 8 & 12 & 24 & 48 & 72 & 96 \\
\hline & \multicolumn{7}{|c|}{ Disappearance of DM $(\%)^{1}$} \\
\hline Ground corn & 19.58 & 32.04 & 36.95 & 47.78 & 58.75 & 63.02 & 64.68 \\
\hline Whole corn & 20.42 & 31.84 & 36.44 & 46.92 & 58.24 & 63.08 & 65.15 \\
\hline \multirow[t]{2}{*}{ Whole corn treated with urea } & 20.33 & 31.63 & 36.15 & 46.36 & 57.17 & 61.66 & 63.53 \\
\hline & \multicolumn{7}{|c|}{ Disappearance of $\operatorname{ADF}(\%)^{2}$} \\
\hline Ground corn & 7.05 & 15.62 & 19.39 & 28.91 & 41.96 & 49.74 & 54.38 \\
\hline Whole corn & 8.53 & 16.64 & 20.21 & 29.28 & 41.78 & 49.33 & 53.87 \\
\hline \multirow[t]{2}{*}{ Whole corn treated with urea } & 7.65 & 15.48 & 18.99 & 28.12 & 41.39 & 49.99 & 55.56 \\
\hline & \multicolumn{7}{|c|}{ Disappearance of cellulose $(\%)^{3}$} \\
\hline Ground corn & 5.80 & 14.68 & 18.63 & 28.76 & 43.06 & 51.98 & 57.54 \\
\hline Whole corn & 6.88 & 15.90 & 19.94 & 30.48 & 45.85 & 55.85 & 62.36 \\
\hline Whole corn treated with urea & 7.83 & 15.27 & 18.60 & 27.24 & 39.74 & 47.79 & 52.98 \\
\hline
\end{tabular}

${ }^{1} \mathrm{YDM}=20.11+45.65[1-\operatorname{EXP}(-0.03712 \mathrm{t})] ; \mathrm{r}^{2}=0.9177$

${ }^{2} \mathrm{YADF}=7.74+54.88[1-\operatorname{EXP}(-0.02022 \mathrm{t})] ; \mathrm{r}^{2}=0.9436$

${ }^{3} \mathrm{YCEL}=6.84+61.03[1-\operatorname{EXP}(-0.01864 \mathrm{t})] ; \mathrm{r}^{2}=0.9402$

Table 3 - Potential disappearance, potential degradation $(a+b)$ and effective degradability of dry weight, acid detergent fiber and sorghum silage cellulose

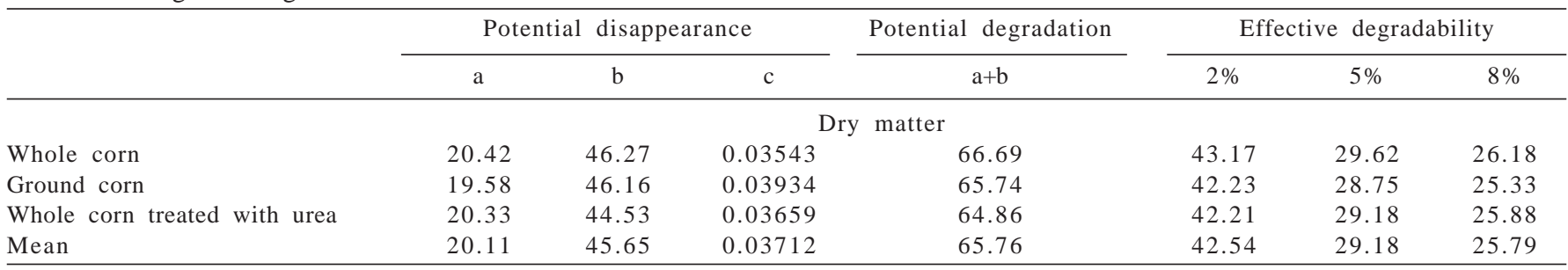


Table 4 - Disappearance potential, degradation potential, time estimated for the beginning of degradation (lag time - hours) and effective degradability of fiber in acid detergent and sorghum silage cellulose

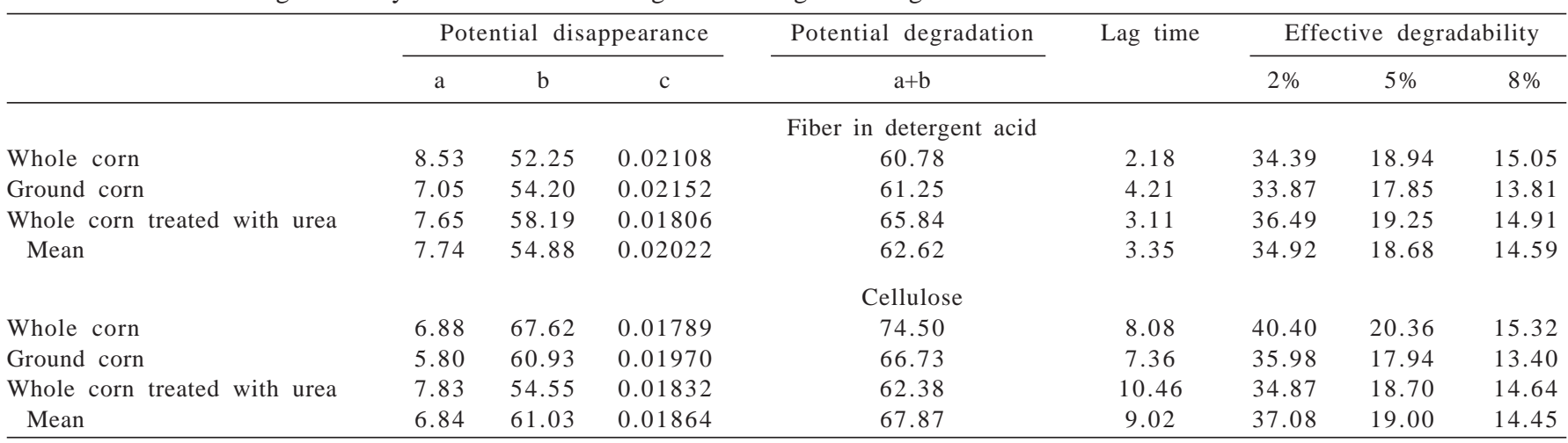

(Table 4). However, Petit (1994) also reported positive values for ADF disappearance for hay (Phleum pratense) and corn silage, with values close to 8 and $15 \%$, respectively.

In the present study, the lag time period, which is the time necessary to begin ruminal degradation by microorganisms after incubation, was expected for all measured parameters, despite of being inferred only for $\mathrm{ADF}$ and cellulose but not for DM and indicating the beginning of degradation immediately after incubation. There was a long estimated duration for the lag time period for cellulose, averaging 9.02 hours, which was also recorded by Grant (1994) for the digestion of neutral detergent fiber, in which $\mathrm{pH}$ was controlled in vitro to 5.5 and a decrease for 2 hours was recorded when $\mathrm{pH}$ approached 6.8. Mertens \& Loften (1980) observed a linear increase in lag time in relation to fiber degradation following an increasing addition of starch in an in vitro experiment, but did not observe any effect on the degradation rate - only a decrease in degradation potential with the addition of starch. This same effect could have occurred in the present experiment, not because of the amount of starch, but because of the possible differences in the velocity of degradation of cornstarch, which accounted for nearly $77 \%$ of the total starch in the tested diets.

In this experiment, because $\mathrm{pH}$ of the ruminal liquid was not significantly influenced by experimental diets (Table 5), it can be inferred that corn treatment did not affect rumination and saliva production, which was sufficient to buffer ruminal fluid. The diet containing whole starch grain led to an average $\mathrm{pH}$ higher than that of other diets, reaching $0.12 \mathrm{pH}$ units higher than that associated with the diet with grains ground into grits.

At time zero (initial sampling), $\mathrm{pH}$ was above 6.8 in all diets and became lower after feeding (Figure 1). Nevertheless, Galyean et al. (1976) showed the influence of the mode of processing corn grains on ruminal $\mathrm{pH}$, which averaged 6.2 possibly because of the high level of concentrate in the diet (85\%). Galyean et al. (1979) compared whole corn grains to

Table 5 - pH, N-amoniacal and bacterial activity in the ruminal fluid of dairy steer fed experimental diets

\begin{tabular}{|c|c|c|c|c|}
\hline \multirow[t]{2}{*}{ Parameter } & \multicolumn{3}{|c|}{ Diet } & \multirow[t]{2}{*}{ Regression / $\mathrm{R}^{2}$} \\
\hline & Ground corn & Whole corn & $\begin{array}{l}\text { Whole corn } \\
\text { treated with urea }\end{array}$ & \\
\hline N-amoniacal (mg N/100 mL) & $17.13 a$ & $17.99 a$ & $13.29 b$ & $\begin{array}{l}\mathrm{NH}_{3} \text { (ground corn grain) }=13.18+18.37 * \mathrm{t}-9.03 * \mathrm{t}^{2}+ \\
1.43 * \mathrm{t}^{3}-0.074 * \mathrm{t}^{4} / \mathrm{R}^{2}=0.981 \\
\mathrm{NH}_{3}\left(\text { whole corn grain) }=14.03+18.37 * \mathrm{t}-9.03 * \mathrm{t}^{2}+\right. \\
1.43 * \mathrm{t}^{3}-0.074 * \mathrm{t}^{4} / \mathrm{R}^{2}=0.981 \\
\mathrm{NH}_{3}(\text { whole corn grain treated with urea })=9.34+18.37 * \mathrm{t}- \\
9.03 * \mathrm{t}^{2}+1.43 * \mathrm{t}^{3}-0.074 * \mathrm{t}^{4} / \mathrm{R}^{2}=0.981\end{array}$ \\
\hline Bacterial activity (seconds) & $230.34 a$ & $124.11 b$ & 113.91b & $\begin{array}{l}\text { Ground corn grain }=412.57-390.64 * \mathrm{t}+198.79 * \mathrm{t}^{2}- \\
37.05 * \mathrm{t}^{3}-2.22 * \mathrm{t}^{4} / \mathrm{R}^{2}=0.9771 \\
\text { Whole corn grain }=193.99-146.16 * \mathrm{t}+76.70 * \mathrm{t}^{2}- \\
14.47 * \mathrm{t}^{3}-0.86 * \mathrm{t}^{4} / \mathrm{R}^{2}=0.9723 \\
\text { Whole corn grain treated with urea }=153.12-100.36 * \mathrm{t}+ \\
67.22 * \mathrm{t}^{2}-14.43 * \mathrm{t}^{3}-0.91 * \mathrm{t}^{4} / \mathrm{R}^{2}=0.9750\end{array}$ \\
\hline
\end{tabular}


grains ground to three different granulometries and did not find any significant differences in the ruminal fluid in the tested animals.

The $\mathrm{pH}$ curve of the ruminal fluid of the animals right after feeding showed irregular behavior, with a peak at 3.5 hours, differing from the expectation of a constant drop, followed by a new increase over time. The explanation for the tendency for the $\mathrm{pH}$ to be maintained from 6.60 to 6.65 after feeding, from 1.5 to 5 hours after the beginning of the experiments, with a peak at 3.5 hours, could be a possibly higher rumination in that interval, which kept buffered the ruminal fluid. Murphy et al. (1994) showed that, immediately after feeding, ruminal $\mathrm{pH}$ was lower for steer fed diets containing whole corn grains (5.95) compared to those fed laminated corn grains (6.26), for until two hours (the lowest value). Later, there was a significant inversion until nine hours after feeding.

The processing of corn grains did not affect the concentration of amoniacal nitrogen in the rumen, with a peak of $5 \mathrm{mg} \mathrm{N} / 100 \mathrm{~mL}$ of fluid one hour after feeding. Coombe et al. (1979) also did not detect any influence of the diet on ruminal $\mathrm{pH}$, although the concentration of amoniacal nitrogen was influenced by the application of $\mathrm{NaOH}$ in the forage, resulting in a low level of ruminal fluid (0.7-1.3 mgN/100mL).

The levels of amoniacal nitrogen obtained for each treatment curve were similar $(\mathrm{P}>0.05)$, starting from around $12.17 \mathrm{mg} \mathrm{N} / 100 \mathrm{~mL}$ of ruminal fluid at time zero, to a peak of $24.42 \mathrm{mg} \mathrm{N} / 100 \mathrm{~mL}$ after 1.5 hours after feeding, and decreasing to $9.91 \mathrm{mg} \mathrm{N} / 100 \mathrm{~mL}$ after 8.5 hours. Animals were not fed after morning feeding, which reduced the amount of protein and urea available in the rumen therefore limiting the level of degraded amoniacal nitrogen,

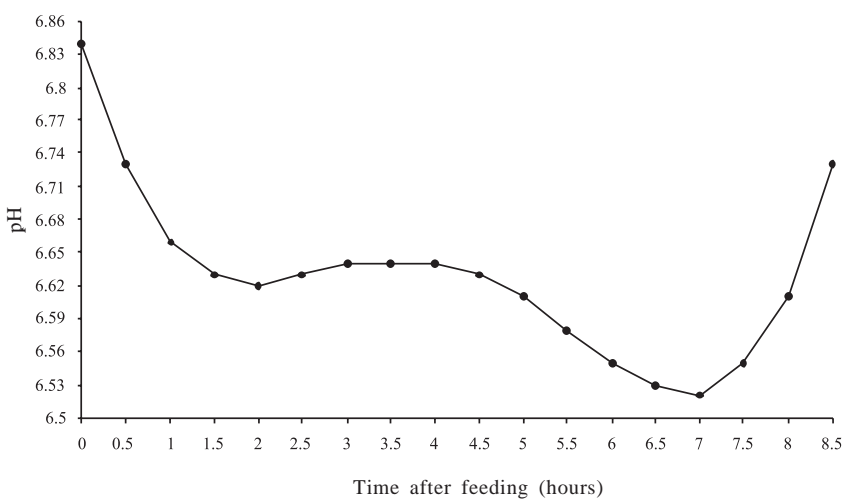

Figure 1- Ruminal fluid pH in dairy steers after feeding. particularly the readily degradable fraction, whose degradation was significant until 1.5 hours after feeding. After that period, ruminal absorption and the use by microorganisms reduced the concentration of amoniacal nitrogen. The animals fed diet containing whole corn grains always showed the lowest levels of ammonia $(\mathrm{P}<0.05)$ (Figure 2).

The observed levels of ammonia in the present experiment were similar to those reported by Kang-Meznarich \& Broderick (1981) and Murphy et al. (1994) and considered as excellent for the adequate digestion of food in the rumen and, therefore for maximal microbial growth. According to Kang-Meznarich \&Broderick (1981), from 3.3 to $8.50 \mathrm{mgN} / 100 \mathrm{~mL}$ of ruminal fluid, there are not any differences in the ruminal digestion of DM, in the digestion rate and in the maximal microbial growth in diets containing $74 \%$ of corn grain. Ludden \& Cecava (1995) also showed this tendency when analyzing amoniacal nitrogen and ruminal pH in the presence of different protein sources with ground corn and did not find any effect of the diet on $\mathrm{pH}$ and amoniacal concentration, which remained $3.46 \mathrm{mg} \mathrm{N} / 100 \mathrm{~mL}$ of ruminal fluid.

The measured bacterial activity was very sensitive. There was a significant difference from the average activity in ground corn when compared to to whole corn and corn treated with urea (Table 5). The bacterial activity remained at an average that was classified as moderate for the ground corn and active for both whole and corn treated with urea. For diets with whole grains and grains treated with urea, the activity remained from active to moderate, whereas in the case of the diet based on ground corn, the activity ranged from reduced to active (Figure 3 ), which is expected and easy to be explained if the ruminal $\mathrm{pH}$ had

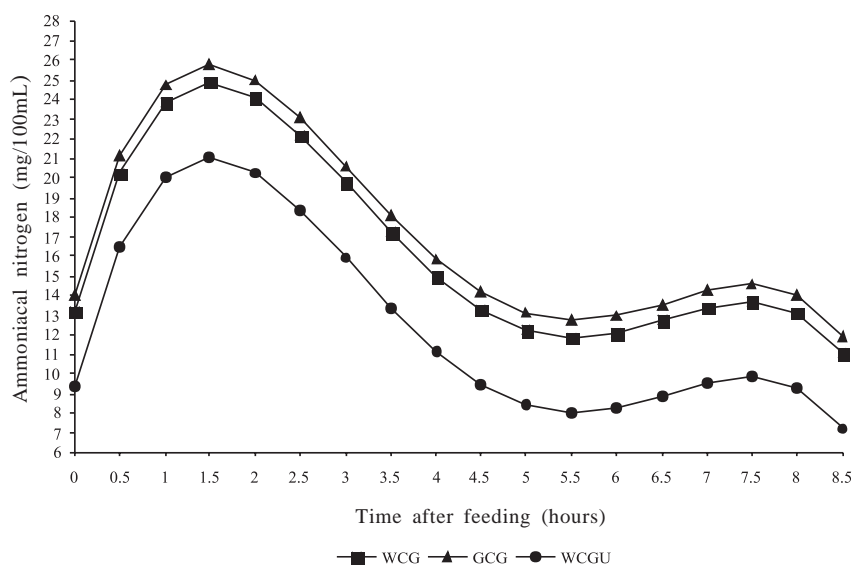

Figure 2 - Amoniacal nitrogen in the ruminal fluid after feeding whole corn grain (WCG), ground corn grains (GCG), and whole corn grain treated with urea (WCGU). 
differed among the experimental groups fed different diets, which did not occur.

Ground corn grain diet was always associated with a lower bacterial activity in comparison to the other diets. In general, the peaks of maximal bacterial activity coincided with the lowest values of $\mathrm{pH}$, confirming that, during those collection times, the highest concentration levels of fermentation products due to the higher bacterial activity, as well as the lower $\mathrm{pH}$ occured. This was also found for the level of amoniacal nitrogen, inasmuch as the maximal peak coincided with the first peak in the maximal bacterial activity and to the first $\mathrm{pH}$ reduction right after feeding. Therefore, the large amount of substrate that reached the rumen was rapidly fermented due to the high bacterial activity resulting from a possible elevation in the concentration of fermentation products (volatile fatty acids) and the decrease in $\mathrm{pH}$.

The similarity in the results of different diets might have happened because of the ability of young ruminants to chew corn grains, causing the natural rupture of the pericarp - the layer that surrounds the seed -exposing the starch granules and the remaining nutrients from the grain to microbial fermentation and to the action of digestive enzymes present in the gastrointestinal tract of the animal. These data corroborate the information provided by Orskov (1990) on the higher ability for chewing in young bovines up to $150 \mathrm{~kg}$ of live weight. Accordingly, in those cases, it would be advantageous to provide whole corn grains to the animals.

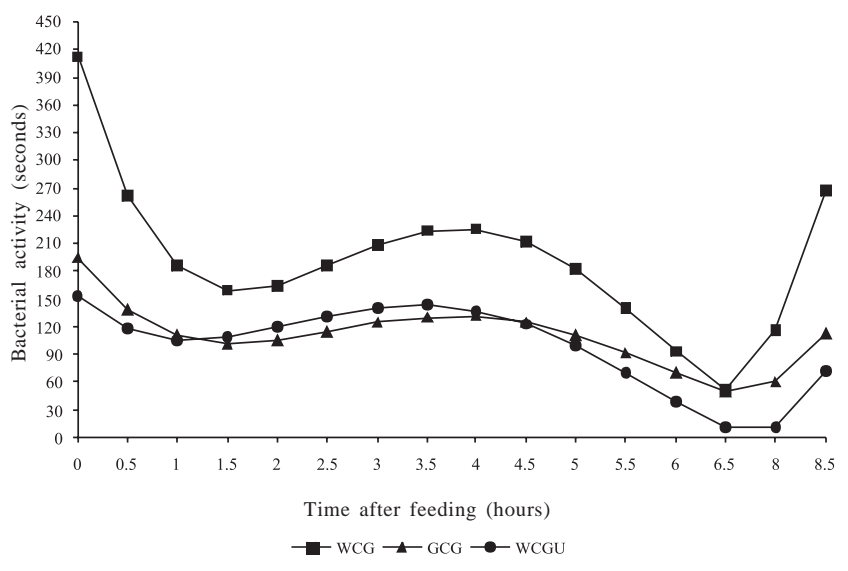

Figure 3 - Bacterial activity in the ruminal fluid when measured by the time for the reduction of methylene blue, adjusted according to the time after feeding and to the experimental diets: whole corn grain (WCG), ground corn grains (GCG), and whole corn grain treated with urea (WCGU).
The amount and availability of carbohydrates and nitrogen are directly related with microbial activity (Theurer, 1986), confirming that, based on the results of the present study, these parameters were kept balanced in spite of corn treatment. This also influenced the concentration of free hydrogen-ion concentration, which resulted in a ruminal $\mathrm{pH}$, which was similar among the tested diets, with no influence on the fiber degradation of the forage, as it was expected in any of the studied postfeeding intervals.

\section{Conclusions}

For dairy steer, the grinding of corn grains and the treatment of whole grains with urea do not interfere with the $\mathrm{pH}$ of the ruminal fluid nor with the ruminal degradability of dry matter, acid detergent fiber and cellulose in sorghum silage. The concentration of amoniacal nitrogen in the ruminal fluid is lower in animals fed whole corn grains treated with urea, whereas microbial activity is lower when the animals are fed corn grains ground into grits.

\section{References}

AGRICULTURAL AND FOOD RESEARCH COUNCIL - AFRC. Nutritive requirements of ruminants animals protein. Nutrition Abstracts and Reviews (Series B), v.62, n.12, p.787-835, 1992.

ASSOCIATIONS OF OFFICIAL AGRICULTURAL CHEMISTS AOAC. Official methods of analysis. 14.ed. Washington D.C., 1984. 1141p.

ALCADE, C.R.; ANDRADE, P. Avaliação da granulometria do milho na digestibilidade aparente de rações utilizando silagem de milho com levedura ou farelo de soja em bovinos. In: REUNIÃO ANUAL DA SOCIEDADE BRASILEIRA DE ZOOTECNIA, 34., 1997, Juiz de Fora. Anais... Juiz de Fora: Sociedade Brasileira de Zootecnia, 1997. p.43-45.

ALLEN, M.S. Relationship between fermentation acid production in the rumen and the requirement for physically affective fiber. Journal of Dairy Science, v.80, n.7, p.1447-1462, 1997.

BEAUCHEMIN, K.A.; McALLISTER, T.A.; DONG, V. et al. Effects of mastication on digestion of whole cereal grains by cattle. Journal of Animal Science, v.72, n.2, p.236-246, 1994.

BÜRGER, P.J.; PEREIRA, J.C.; COELHO DA SILVA, J.F. et al. Taxas de passagem e cinética da degradação ruminal em bezerros holandeses alimentados com dietas contendo diferentes níveis de concentrado. Revista Brasileira de Zootecnia, v.29, n.1, p.225-235, 2000.

COOMBE, J.B.; DINIUS, D.A.; WHEELER, W.E. Effect of alkali treatment on intake in digestion of barley straw by beef steers. Journal of Animal Science, v.49, n.1, p.169-176, 1979.

DIRKSEN, G. Indigestiones en el bovino. Hannover: SchnetztorVerlag, 1981. 76p.

FENNER, H. Methods for determining total volatile bases in rumen fluid by steam distillation. Journal of Dairy Science, v.48, n.3, p.249-251, 1965.

GALYEAN, M.L.; WAGNER, D.G.; JOHNSON, R.R. et al. Site extend of starch digestion in steers fed processed corn rations. Journal of Animal Science, v.43, n.5, p.1088-1094, 1976. 
GALYEAN, M.L.; WAGNER, D.G.; OWENS, F.N. et al. Corn particle size and site and extent of digestion by steers. Journal of Animal Science, v.49, n.1, p.204-210, 1979.

GOERING, H.K.; Van SOEST, P.J. Forage fiber analisis. Washington, D.C.: USDA, 1970. 20p. (Agricultural Handbook, 379).

GRANT, R.J. Influence of corn sorghum starch on the in vitro kinetics of forage fiber digestion. Journal of Dairy Science, v.77, n.6, p.1563-1569, 1994.

HERNANDEZ, F.I.L.; SANCHEZ, L.M.B.; VIEIRA, R.A.M. et al. Desaparecimento ruminal e digestibilidade intestinal e total da matéria seca e proteína bruta de alguns suplementos concentrados. Revista Brasileira de Zootecnia, v.27, n.4, p.777-782, 1998.

HOBSON, P.N.; STEWARD, C.S. The rumen microbial ecosystem. 2.ed. London: Blackie Academic \& Professional (Chapman \& Hall), 1997. 719p.

HUNTINGTON, G.B. Hepatic urea synthesis and site and rate of urea removal from blood beef steers fed alfafa hay or a high concentrate diet. Canadian Journal of Animal Science, v.69, p.215-223, 1989.

KANG-MEZNARICH，J.H.; BRODERICK，G.A. Effects of incremental urea supplementation on ruminal ammonia concentration and bacterial protein formation. Journal of Animal Science, v.51, n.2, p.422-431, 1981.

LUDDEN, P.A.; CECAVA, M.J. Supplemental protein sources for steers fed corn-based diets: I. Ruminal characteristics and intestinal amino acid flows. Journal of Animal Science, v.73, n.5, p.1466-1475, 1995.

McDONALD, I. A revised model for the estimation of protein degradability in the rumen. Journal of Agricultural Science, v.96, p.251-252, 1981.

MERTENS, D.R.; LOFTEN, J.R. The effect of starch on forage fiber digestion kinetics in vitro. Journal of Dairy Science, v.63, n.9, p.1437-1446, 1980.

MURPHY, T.A.; FLUHARTY, F.L.; LOERCH, S.C. The influence of intake level and corn processing on digestibility and ruminal metabolism in steers fed all-concentrate diets. Journal of Animal Science, v.72, n.6, p.1608-1615, 1994.

OLIVEIRA, M.V.M.; VARGAS JUNIOR, F.M.; BONECARRÈRE SANCHEZ, L.M. et al. Degradabilidade ruminal e digestibilidade intestinal de alimentos por intermédio da técnica in situ associada à do saco de náilon móvel. Revista Brasileira de Zootecnia, v.32, n.6, p.2023-2031, 2003.

ORSKOV, E.R.; McDONALD, I. The estimation of protein degradability in the rumen from incubation measurements weighted according to rate of passage. Journal of Agricultural Science, v.92, p.499-503, 1979.

ORSKOV, E.R. Alimentación de los rumiantes: principios e práctico. Zaragoza: 1990. 115p.

OWENS, F.N.; GOETSCH, A.L. Fermentación ruminal. In CHURCH, D.C. (Ed.) El rumiante fisiología digestiva y nutrición. Zaragoza: Editorial Acribia, 1993. p.159-190.

PETIT, H.V. Forage quality and its limiting factors for meat production. In: REUNIÃO ANUAL DA SOCIEDADE BRASILEIRA DE ZOOTECNIA, 31., 1994, Maringá. Anais... Maringá: SBZ, 1994. p.61-80.

POTTER, G.D.; McNEILL, J.W.; RIGGS, J.K. Utilization of processed sorghum grain proteins by steers. Journal of Animal Science, v.32, n.3, p.540, 1971.

ROONEY, L.W.; PFLUGFELDER, R.L. Factors affecting starch digestibility with special emphasis on sorghum and corn. Journal of Animal Science, v.63, n.5, p.1607-1623, 1986.

SILVA, J.F.C.; LEÃO, M.I. Fundamentos de nutrição de ruminantes. Piracicaba: Livroceres, 1979. 384p.

STATISTIC ANALYSIS SYSTEM - SAS. User's guide. Cary: SAS Institute, USA, 2003. 2694p.

THEURER, C.B. Grain processing effects on starch utilization by ruminants. Journal of Animal Science, v.63, n.4, p.1649-1662, 1986.

VARGAS JUNIOR, F.M.; SANCHEZ, L.M.B.; WECHSLER, F.S. et al. Influência do processamento do grão de milho na digestibilidade de rações e no desempenho de bezerros. Revista Brasileira de Zootecnia, v.37, n.11, p.2056-2062, 2008. 